\title{
Assays for Determining Pertussis Toxin Activity in Acellular Pertussis Vaccines
}

\author{
Kevin Markey *, Catpagavalli Asokanathan and Ian Feavers \\ Division of Bacteriology, National Institute for Biological Standards and Control (NIBSC), Blanche Lane, \\ South Mimms, Potters Bar, Hertfordshire EN6 3QG, UK \\ * Correspondence: Kevin.Markey@nibsc.org
}

Received: 16 June 2019; Accepted: 13 July 2019; Published: 17 July 2019

\begin{abstract}
Whooping cough is caused by the bacterium Bordetella pertussis. There are currently two types of vaccines that can prevent the disease; whole cell vaccines (WCV) and acellular vaccines $(\mathrm{ACV})$. The main virulence factor produced by the organism is pertussis toxin (PTx). This toxin is responsible for many physiological effects on the host, but it is also immunogenic and in its detoxified form is the main component of all ACVs. In producing toxoid for vaccines, it is vital to achieve a balance between sufficiently detoxifying PTx to render it safe while maintaining enough molecular structure that it retains its protective immunogenicity. To ensure that the first part of this balancing act has been successfully achieved, assays are required to accurately measure residual PTx activity in $\mathrm{ACV}$ products accurately. Quality control assays are also required to ensure that the detoxification procedures are robust and stable. This manuscript reviews the methods that have been used to achieve this aim, or may have the potential to replace them, and highlights their continuing requirement as vaccines that induce a longer lasting immunity are developed to prevent the re-occurrence of outbreaks that have been observed recently.
\end{abstract}

Keywords: pertussis toxin; acellular pertussis vaccine; vaccine safety; histamine sensitization test; $\mathrm{CHO}$ cell clustering assay; in vitro alternative methods

Key Contribution: This review describes the methods that have been used to measure pertussis toxin activity in acellular pertussis vaccines in order to ensure vaccine safety.

\section{Introduction}

\subsection{Pertussis Disease}

The Gram-negative bacterium Bordetella pertussis is the aetiological agent of whooping cough. This is a serious, highly contagious respiratory disease, especially dangerous in infants who are either too young to have been vaccinated or have not received their full vaccination series [1]. The disease normally presents as a paroxysmal cough with a characteristic whoop. The cough can be followed by vomiting and symptoms can last for several months. More severe complications include pneumonia, pulmonary hypertension, febrile seizures, encephalopathy and brain haemorrhages [2,3]. There are several virulence factors associated with B. pertussis such as pertussis toxin (PTx), dermonecrotic toxin, tracheal cytotoxin and adenylate cyclase toxin. Proteins that are involved in cell binding such as filamentous haemagglutinin (FHA), fimbriae (FIM) and pertactin (Prn) also play a role in pathogenesis [3-5]. The production of these factors is controlled by a two-component signal transduction system (BvgAS) which is regulated by environmental factors in the host such as temperature [6-8]. The initial step in pathogenesis is adherence to tracheal epithelium followed by colonisation leading to local damage in the airways. The age and immunocompetence of the patient have an effect on the severity of disease with infants most seriously affected [6]. 


\subsection{Pertussis Vaccines}

The first vaccines developed to prevent pertussis infection consisted of killed whole cells (WCV). These have been widely administered internationally since the 1940s, and their use has resulted in a marked reduction in the morbidity and mortality associated with pertussis disease $[9,10]$. They are still the most commonly administered type of pertussis vaccine globally mainly due to their lower cost $[11,12]$. Whole cell vaccines comprise specific strains that are grown in conditions that ensure the expression of the virulent phase 1 phenotype. The strains are then subsequently heat- or formalin inactivated $[4,13]$. The strains used are chosen to include the agglutinogen serotypes 1,2 and 3 . While one strain may cover all three types, usually a combination of different strains expressing serotypes 2 and 3 are used in the production of WCV as all B. pertussis strains express agglutinogen 1 . Whole cell vaccines induce mainly cellular based immune responses resulting in long lasting immunity in humans and have been demonstrated to prevent carriage in a non-human primate model $[5,14]$.

However, some side-effects have been associated with the administration of WCVs. These include mild symptoms such as, redness around the injection site to very rare severe symptoms such as febrile seizure [15-18]. Although these reactions had no long term sequalae they resulted in the suspension of WCV programs in some countries and had a negative effect on vaccine compliance in others [19-22]. This led to the development of two types of acellular pertussis vaccines (ACV) that are less reactogenic. The first type was developed in Japan as co-purified preparations of PTx and FHA [21,23]. The second type contains more highly purified PTx and FHA along with other B. pertussis antigens in many different concentrations and combinations [24,25]. The main component present in all ACV vaccines is PTx in its detoxified form (PTd). Most ACV products also contain other purified pertussis antigens such as FHA, Fim $2 \& 3$ and Prn as these antigens are considered to be important in the generation of a protective immune response [26]. The purification process means that reactogenic components of the WCV vaccine, such as lipopolysaccharide, are omitted from the final vaccine formulation. The resulting ACVs are far less reactogenic with no serious side effects, while remaining immunogenic [26]. For the final vaccine formulation pertussis antigens are adsorbed to an adjuvant, which are normally alum based such as aluminium phosphate or aluminium hydroxide. Finally, ACVs are also usually formulated in combination with components to protect against other diseases including tetanus and diphtheria toxoids, inactivated polio virus and Haemophilus influenza B polysaccharide [27-29].

Since the widespread introduction of vaccination against pertussis there has been a marked reduction in the number of cases in whooping cough, but recent years have seen outbreaks in areas with a high ACV vaccination coverage such as Europe, USA and Australia [30-38]. There are number of possible reasons for these outbreaks and increased number of cases. Firstly, ACVs predominantly induce a humoral, or Type $2 \mathrm{~T}$ helper cell (Th2), immune response as opposed to the cellular Th1 and Th17 immunity induced by WCV and natural infection and which are associated with protection and clearance. This Th2 response may also result in poorer long-term protection compared to WCV [5,6,39-43]. Furthermore, it has been demonstrated in baboon models that ACVs do not prevent colonisation and transmission [14]. Also, bacterial isolates that do not express the antigens used in ACVs, such as Prn and even PTx, have been identified in a number of countries along with antigenic variation may result in vaccine escape [41,44-49]. Finally, improved awareness and surveillance methods may also have resulted in the identification of cases that would otherwise have been undiagnosed previously [50,51]. For these reasons, there is continued interest in developing improved ACVs, less reactogenic WCVs, and outer membrane vesicles-based vaccines among others $[3,13,52,53]$.

\subsection{Structure of PTx}

PTx is a multimeric $105 \mathrm{kDa}$ protein and has an A-B type structure $\left(\mathrm{AB}_{5}\right)$ typical of many other bacterial toxins, including cholera toxin [54]. The A-protomer is a monomer and is enzymatically active. The B-oligomer binds to carbohydrates on the target cell membrane. While the A-protomer of PTx is comprised of just one subunit peptide (S1) the B-protomer has five subunits of S-2 through to S-5 with two S-4 subunits [55-57]. Intact B-oligomer is required for binding of the toxin to the cell surface 
and enables entry of the A-protomer into the cells by translocation across the plasma membrane by retrograde transport $[58,59]$. This process involves the A-subunit moving through the pore which is created in middle of the B-pentemer [60]. Once inside the cell, the A-subunit is trafficked to the Golgi apparatus and then on to the endoplasmic reticulum (ER) where the A-protomer dissociates from the rest of the toxin. The A-subunit is then exported to the cytoplasm through ER-associated degradation (ERAD) [61,62]. In the cytoplasm the enzymatic activity of the A-subunit ADP-ribosylates G-proteins [63-65]. This results in a wide range of physiological effects including lymphocyctosis, insulin secretion, histamine sensitization, mitogenesis, melanocyte stimulation, $\mathrm{T}$ and B-lymphocyte stimulation, inhibition of neutrophil chemotaxis and monocyte migration $[59,66]$. Even though it has been demonstrated that the binding of the B-subunit only has a physiological effect for monitoring PTx activity in the context of vaccine safety both A and B subunit functionality need to be assessed.

In its native form PTx is too toxic to be used directly in vaccines and therefore must be carefully detoxified whilst ensuring that the molecule retains its protective immunogenicity. The detoxification process therefore needs to be well controlled to result in a stable product that is sufficiently detoxified and does not revert back to toxicity while maintaining its protective epitopes. Detoxification is primarily a chemical process. Most commonly glutaraldehyde and formaldehyde, either individually or in combination, are used in detoxification. The process of chemical detoxification typically involves incubating the toxin with glutaraldehyde for $2 \mathrm{~h}$ at $25^{\circ} \mathrm{C}$ or formaldehyde at $40{ }^{\circ} \mathrm{C}$ for 7 days [67]. Detoxification by hydrogen peroxide is also used, for example in Denmark, and has been shown to result in less disruption of epitopes compared with formaldehyde treatment [68-70].

Chemical detoxification usually results in the crosslinking of amino acid residues of the toxin but different procedures using different reagents and conditions have been shown to result in distinct conformational changes and epitope binding patterns [71-77]. Glutaraldehyde treatment results in the crosslinking of lysine residues. There are no such residues in the S1 subunit of PTx but several in the subunits that comprise the B-oligomer [78,79]. Glutaraldehyde detoxification results in the loss of the molecule's ability to bind to the cell membrane and hence enter the cell to express its toxic activity. The ADP-ribosyl transferase activity is not affected by glutaraldehyde detoxification [67].

Formaldehyde reacts with the amino group of the $\mathrm{N}$-terminal and the side-chains of arginine, cysteine, histidine, and lysine residues [75]. Since most of these residues are found in both A and B subunits treatment with formaldehyde leads to a reduction of both binding and enzymatic activities of the toxin [67]. Formaldehyde treatment also results in the loss of ability of the protective monoclonal antibody $1 \mathrm{~B} 7$ to bind to the toxin $[74,80]$.

A number of genetically modified PTxs (PTgs) have also been developed whereby mutations in the A subunit have resulted in a loss of toxicity. These toxoids have two amino acid substitutions in the active site of the enzyme that result in the loss of ADP-ribosylation activity. They have been found to be safe and elicit an immunogenic response similar to, or better than, the native PTx antigen [81-87]. It may also be possible to engineer B. pertussis strains that express PTg in higher amounts than native strains [88,89].

Given the delicate balance that needs to be achieved to reduce toxicity to a level proven to be safe in clinical trials while retaining protective immunogenicity, the ability to accurately measure residual PTx activity is critical to ensure ACV vaccines are safe. It is also important to demonstrate the stability of the detoxification process thus ensuring that the toxoid does not revert back to toxicity during storage. To confirm stability and the absence of reversion final ACVs are often incubated at $37^{\circ} \mathrm{C}$ for 4 weeks and the PTx activity assessed [90-92]. Therefore, methods to accurately measure any PTx activity that may be present in bulk toxin and toxoid preparations, and in final formulations of vaccines are required to ensure vaccine safety and monitor batch-to-batch variation [4]. 


\section{Specific Tests for PTx Toxicity}

\subsection{Lethal Histamine Sensitization Test (Lethal HIST)}

Following the introduction and widespread use of $\mathrm{ACVs}$ the lethal histamine sensitization test (HIST) in mice was for a long time the only means for detecting residual PTx toxicity in final products along with in toxin and toxoid bulks. It was first developed to detect PTx activity in WCV vaccines but was subsequently used for ACV products in Japan, then the US and Europe [93]. It is based on the principle that mice are inherently resistant to histamine toxicity but become sensitive after exposure to PTx [93-97].

There are many variations of the lethal HIST used globally (Table 1), however, they broadly follow a similar format. Mice are divided into groups of pre-defined numbers which receive either a dose of test vaccine stored at $2-8{ }^{\circ} \mathrm{C}$ to check for residual toxicity or vaccine incubated at $37^{\circ} \mathrm{C}$ for 4 weeks to monitor reversion to toxicity. Groups may also receive a reference vaccine with established clinical safety for comparison. All forms of the assay also include groups which receive active PTx as positive control at a dose that has been defined to cause death in pre-defined number of mice to ensure the sensitivity of the mice to histamine challenge. Three to five days later the mice are challenged with histamine and monitored for $24 \mathrm{~h}$. If the mice have been exposed to active PTx they can experience anaphylactic shock leading to a reduction in body temperature, pain, distress and death. The number of deaths in each group following challenge are recorded. The validity criteria of the various form of the assay also vary as does the acceptance criteria for the test vaccines to pass (Table 1). Generally, deaths are required in the positive control groups to demonstrate that the mice are sensitive to the histamine challenge and the level of PTx activity (i.e., deaths) in the test vaccine groups should be at, or below, an acceptable level or reference vaccine preparation [91,92,98].

\subsection{Temperature Histamine Sensitization Test (Temperature HIST)}

A refinement to the lethal HIST assay was developed and used successfully in Japan and other countries in Asia for testing ACVs. This assay is based on the reduction in body temperature observed in PTx exposed mice following challenge with histamine. It uses similar groups and procedures as the lethal HIST but the body temperature of the mice is measured $30 \mathrm{~min}$ after histamine challenge [99]. Temperature can be measured either with a rectal/dermal thermometer or a thermal camera. This method provides a quantitative estimate of the PTx activity of a test vaccine relative to a PTx reference standard which has been assigned histamine sensitization units (HSU) or International Units (IU). The accepted level of PTx in test vaccines also varies by region with 0.4 HSU the level in Japan and 0.8 HSU in China (Table 1) [90,100-102]. The animals can then be culled once the temperature reading has taken place and thus reduce the severity of the procedure. It is, however, still considered a severe assay from an animal welfare viewpoint as a large proportion of the mice that die in the assay do so in the first $30 \mathrm{~min}$ after challenge [99].

Both forms of the HIST assay can be used to measure the levels of PTx activity in samples by comparing the drop in temperature, or deaths per group, for a range of doses to the responses in a reference preparation [103-105]. While both death and changes in body temperature have been found to be dose dependent they do not seem to be linked and the modes of action may not be the same $[99,102]$. 
Table 1. Histamine sensitisation test requirements specified in regulatory guidelines (taken from Arcinega et al., 2016 and Hoonakker et al., 2017 [93,102]).

\begin{tabular}{|c|c|c|c|c|c|c|}
\hline Requirement & WHO & $\mathrm{EU}^{1}$ & USA & Canada & China & Japan \\
\hline $\begin{array}{l}\text { Requirement } \\
\text { according to }\end{array}$ & TRS 979 & Ph. Eur. & License Dossier & Ph. Eur. & Ph. Chin. & Ph. Ja. \\
\hline $\begin{array}{l}\text { Final lot (or bulk)/in } \\
\text { process }\end{array}$ & $\begin{array}{c}\text { Final bulk (one or more } \\
\text { Dilutions) }\end{array}$ & In process and/or final lot & Final lot (or bulk) & Final lot & Bulk and final bulk & Final lot \\
\hline $\begin{array}{l}\text { Injected vaccine } \\
\text { volume }\end{array}$ & 1 or $2 \mathrm{HD}$ & $2 \mathrm{HD}$ & $0.5 \mathrm{~mL}$ & $2 \mathrm{HD}$ & $0.5 \mathrm{~mL}$ & $0.5 \mathrm{~mL}$ \\
\hline $\begin{array}{l}\text { Vaccine sample } \\
\text { storage }\end{array}$ & $\begin{array}{c}1 \text { or more dilutions, } 4{ }^{\circ} \mathrm{C} \\
\text { and or } 37^{\circ} \mathrm{C}\end{array}$ & $4{ }^{\circ} \mathrm{C}$ and $37^{\circ} \mathrm{C}$ & $4^{\circ} \mathrm{C}$ & $4^{\circ} \mathrm{C}$ & $4{ }^{\circ} \mathrm{C}$ and $37^{\circ} \mathrm{C}$ & $4^{\circ} \mathrm{C}$ and $37^{\circ} \mathrm{C}$ \\
\hline Negative Control & Diluent or none & Diluent & Diluent & Diluent & n.s. & n.s. \\
\hline $\begin{array}{l}\text { Positive control (and } \\
\text { number of dilutions) }\end{array}$ & $\begin{array}{c}\text { PTx (one or more } \\
\text { dilutions) }\end{array}$ & PTx (one dilution) & PTx (one) & PTx (one dilution) & PTx (several dilutions) & PTx (several dilutions) \\
\hline $\begin{array}{l}\text { Number of mice per } \\
\text { group }\end{array}$ & $\begin{array}{c}\text { Ten or an appropriate } \\
\text { number }\end{array}$ & 5 & 20 & 5 & 10 & 10 \\
\hline $\begin{array}{l}\text { Minimal number of } \\
\text { groups }\end{array}$ & App. 5 & 3 & App. 3 & 2 & App. 5 & App. 6 \\
\hline Histamine challenge & $\begin{array}{l}\text { defined dose of histamine } \\
\text { (usually } 1 \text { or } 2 \mathrm{mg} \text { ) }\end{array}$ & $2 \mathrm{mg}$ of histamine & $1 \mathrm{mg}$ of histamine & $2 \mathrm{mg}$ of histamine & $2-4 \mathrm{mg}$ of histamine & $4 \mathrm{mg}$ of histamine \\
\hline $\begin{array}{c}\text { Time interval } \\
\text { between sample } \\
\text { administration and } \\
\text { challenge }\end{array}$ & $4-5$ days & 5 days & 5 days & 5 days & 4 days & 4 days \\
\hline Observation period & $30 \mathrm{~min}-24 \mathrm{~h}$ & $24 \mathrm{~h}$ & $24 \mathrm{~h}$ & $24 \mathrm{~h}$ & $30 \mathrm{~min}$ & $30 \mathrm{~min}$ \\
\hline $\begin{array}{l}\text { Minimum animal } \\
\text { number } 1 \text { test }\end{array}$ & App. 50 animals & 15 animals & App. 60 animals & 10 animals & App. 50 animals & App. 60 animals \\
\hline Readout parameter & $\begin{array}{c}\text { Temperature decrease or } \\
\text { death }\end{array}$ & Death & Death & Death & Temperature decrease & Temperature decrease \\
\hline
\end{tabular}


Table 1. Cont.

\begin{tabular}{|c|c|c|c|c|c|c|}
\hline Requirement & WHO & $\mathrm{EU}^{1}$ & USA & Canada & China & Japan \\
\hline Acceptance criteria & $\begin{array}{l}\text { Residual activity of PTx } \\
\text { or the number of animals } \\
\text { that die is not higher than } \\
\text { specified by the NRA. If a } \\
\text { vaccine lot fails in a single } \\
\text { test, it should pass } 2 \\
\text { additional test for release. }\end{array}$ & $\begin{array}{l}\text { The vaccine complies if in } \\
\text { the group that receives } \\
\text { the vaccine stored at } \\
2-8^{\circ} \mathrm{C} \text { or } 37^{\circ} \mathrm{C} \text {, there are } \\
\text { no deaths or no more } \\
\text { deaths than in the group } \\
\text { that receives the reference } \\
\text { vaccine. If one mouse } \\
\text { dies in one or both of the } \\
\text { vaccine groups, repetition } \\
\text { is allowed with the same } \\
\text { number of mice or more. } \\
\text { The vaccine is accepted } \\
\text { when overall death rate is } \\
5 \% \text { or less. }\end{array}$ & $\begin{array}{l}\text { One undiluted single } \\
\text { human dose of } 0.5 \mathrm{~mL} \\
\text { sensitizes no more than } \\
10 \% \text { of mice injected. If } \\
\text { the vaccine fails to meet } \\
\text { the criterion in a first test, } \\
\text { it should pass } 2 \\
\text { additional tests. }\end{array}$ & $\begin{array}{l}\text { The vaccine complies } \\
\text { with the test if in the } \\
\text { group that receives the } \\
\text { vaccine, there is no more } \\
\text { than one death. If more } \\
\text { than one mouse dies in } \\
\text { the negative control } \\
\text { group or the vaccine } \\
\text { group, repetition is } \\
\text { allowed with the same } \\
\text { number of mice or more. } \\
\text { The vaccine is accepted } \\
\text { when overall death rate is } \\
6.25 \% \text { or less. }\end{array}$ & $\begin{array}{l}\text { The histamine-sensitizing } \\
\text { toxicity of both test } \\
\text { samples at } 4^{\circ} \mathrm{C} \text { and } 37^{\circ} \mathrm{C} \\
\text { shall be no higher than } \\
0.8 \mathrm{HSU} / \mathrm{mL} \text { in mice upon } \\
\text { statistical analysis. }\end{array}$ & $\begin{array}{l}\text { The histamine-sensitizing } \\
\text { toxicity of both test } \\
\text { samples at } 4{ }^{\circ} \mathrm{C} \text { and } 37^{\circ} \mathrm{C} \\
\text { shall be no higher than } \\
0.4 \mathrm{HSU} / \mathrm{mL} \text { in mice upon } \\
\text { statistical analysis. }\end{array}$ \\
\hline Validity criteria & $\begin{array}{l}\text { 1. Less than } 5 \% \text { deaths in } \\
\text { the negative control } \\
\text { group. } \\
\text { 2. Demonstrated } \\
\text { sensitivity of mice strain. } \\
\text { 3. When linearity of log } \\
\text { dose-response to PTx is } \\
\text { demonstrated } 1 \text { positive } \\
\text { control group suffice. }\end{array}$ & $\begin{array}{l}\text { 1. No mice die in the } \\
\text { negative control group. } \\
\text { 2. Sensitivity of the mice } \\
\text { is demonstrated (e.g., } 30 \% \\
\text { of the mice die in the } \\
\text { positive control group). } \\
\text { 3. A suitable mouse } \\
\text { strain has a toxin LD50 } \\
\text { between } 6 \text { IU and } 50 \mathrm{IU} \text {. }\end{array}$ & $\begin{array}{l}\text { 1. PTx control group } \\
\text { should show that mice } \\
\text { used are sensitized by a } \\
\text { dose of PTx below } 100 \mathrm{ng} \text {, } \\
\text { in terms of the HSD50. } \\
\text { 2. No more than } 10 \% \text { of } \\
\text { mice should die in the } \\
\text { negative/diluent group. }\end{array}$ & $\begin{array}{l}\text { 1. There are at least } \\
16 \text { mice challenged per } \\
\text { group. } \\
\text { 2. No more than one } \\
\text { mouse dies in the } \\
\text { negative control group. } \\
\text { 3. Sensitivity of the mice } \\
\text { is demonstrated, i.e., at } \\
\text { least seven mice die in the } \\
\text { positive control group } \\
\text { (=43.75\%, mice injected } \\
\text { with } 400 \text { ng of PTx). }\end{array}$ & n.s. & n.s. \\
\hline
\end{tabular}

Pharmacopoeia; Ph. Eur.: European Pharmacopoeia; Ph. Jap.: Japanese Pharmacopoeia; PTx: pertussis toxin; TRS: Technical Report Series; WHO: World Health Organization. 
There are a number of advantages associated with the HIST assays. Firstly, HIST captures all activities of the toxin; binding to the cell membrane, translocation and enzymatic activity once intracellular. The mode of action of PTx in the lethal HIST is thought to mirror that in humans in that the primary mechanism is cell intoxication and the ADP-ribosylation of $G$ proteins in vascular smooth muscles leading to vasodilation and hypovoleamic shock that causes death [93,107-109]. Secondly it is very sensitive for detecting PTx activity. Thirdly, other vaccine components, such as alum adjuvants, do not interfere with the mode of activity. Finally, the potential toxin bioavailability of the vaccine in the mice is a reasonable mimic of the environment of the human vaccine recipient [110].

It has been estimated that the limit of quantification (LOQ) of the HIST assay varies for different PTx materials. For the WHO 1st International Standard for PTx (JNIH-5) the LOQ was estimated to be $1.22 \mathrm{IU}$ per animal and $1.11 \mathrm{IU}$ per animal for European Directorate for the Quality of Medicines and HealthCare's (EDQM) BRP batch 1 [111]. These estimates were calculated using data published in an EDQM collaborative comprising 25 assays and three mouse strains [105,111]. The EDQM study also estimated that the highest level of residual PTx activity in the licenced ACV based combination vaccines included in the study is approximately 2 IU/SHD [105].

There are several disadvantages associated with the HIST assays. Firstly, while the mechanism of the lethal assay is better understood than the temperature method the mechanisms of both forms are poorly understood. It is also believed that the modes of action of the two methods are not linked as there is no temperature drop that is predictive of death [93]. Secondly, they have poor reproducibility leading to high intra- and inter-laboratory variability. This variability can result in significant repeat testing resulting in the use of many mice. There are many factors that result in a high degree of variation of the assay between laboratories for both forms of HIST assay. These include differences in species, age and gender of the mice used, the time between administering the test samples and the histamine challenge, the dose of histamine and control groups included. A number of international collaborative studies, including the recent study for the establishment of the 2nd WHO International Standard for PTx, have highlighted the large differences in HIST assays performed by laboratories globally [103-105]. Also, Table 1 gives an indication of the various forms if HIST used globally. Also, the fact that a single batch going to multiple markets must pass the various versions of HIST relevant to each market substantially increases the number of animals used. It has recently been estimated that approximately 65,000 mice are used globally in HIST assays per year [102]. On top of this the large number of variations in HIST make it difficult to standardize [4]. Finally, there are ethical concerns about animal welfare as the test can cause severe pain and distress, especially for mice receiving a PTx reference standard. For these reasons HIST has long been regarded as a priority for replacement with in vitro alternative assays $[4,67,93,102,110-112]$. However, following consultations between vaccine manufacturers and national control laboratories, the requirement for testing for residual and reversion to toxicity in final formulated vaccines will be removed from the European Pharmacopoeia in 2020 once the detoxification process has been demonstrated to be robust and stable [106]. Tests for residual toxicity and reversion to toxicity will still be required for new products.

\subsection{CHO Cell Clustering Assay}

Chinese Hamster Ovary $(\mathrm{CHO})$ cells have been used as a bioassay system for other $\mathrm{AB}_{5}$ toxins such as cholera toxin. In the presence of cholera toxin $\mathrm{CHO}$ cells become stretched and elongated $[113,114]$. Hewlett et al. first described a test for PTx activity using $\mathrm{CHO}$ cells. They observed that in the presence of active PTx the cells also exhibited a change in morphology but instead became rounded and formed clusters [115]. This altered morphology was found to be due to the ADP-ribosylation activity of PTx on the cells. It was also found that A-subunit and B-subunit individually exhibited greatly reduced clustering activity compared to the whole molecule. Toxoid forms of PTx also had reduced activity [116]. The assay was developed in a microtitre plate format and has been used to monitor the PTx content of upstream vaccine components such as PTx and PTd non-adjuvanted bulks $[91,98,117]$. In the test a monolayer of $\mathrm{CHO}$ cells is treated with vaccine or reference PTx at a 
range of dilutions. After incubation the plates are observed using an inverted microscope and scored for clustering. The highest dilution of the test sample that results in clustering represents the titre. In this way the test can provide a semi-quantitative estimate of the PTx content of the sample when analysed alongside a reference purified native PTx preparation. Initially the variability of the $\mathrm{CHO}$ assay was found to be greater than the HIST in a number of collaborative studies to calibrate different reference preparations of PTx [104,105]. However, like HIST, this was most likely due to the large differences in reagents and methods used by different participants despite early efforts to develop optimised standard assay conditions [117-119]. To address this high variability a standardised method was developed by the EDQM under the aegis of the Biological Standardisation Programme (BSP). In this standardised method $\mathrm{CHO}-\mathrm{K} 1$ cells should be obtained from specific sources, they should be propagated in a defined medium using a standardised number of passages and the scoring of cells for clustering should follow a defined procedure. This standardised method gave good inter-laboratory reproducibility and transferability for pure PTx [120]. It and other CHO cell clustering assay protocols were not, however, suitable for testing residual PTx activity in final vaccine formulations because some components of the vaccines, such as alum-based adjuvants, proved to be cytotoxic to the $\mathrm{CHO}$ cells $[105,112,120]$. Recently, two modified versions of the assay have been developed that attempt to allow testing of final formulations by overcoming these cytotoxic effects [120]. These methods are referred to as the Direct and Indirect methods and were also developed under the auspices of the EDQM. For the Direct method vaccine preparations are sufficiently diluted to negate the toxic effects of vaccine components and the diluted samples are added directly to the cells. With the Indirect method the vaccine preparations are centrifuged, and the supernatant discarded before the pellet is resuspended in culture media. The resuspended pellet is then added to microtitre plate wells which contain a semi-permeable membrane. This membrane is above the $\mathrm{CHO}$ cells and prevents the vaccine adjuvant coming into contact with them [120]. A comparison of the modified CHO assays was performed in an EDQM study (BSP114) using a common set vaccine samples spiked with known concentrations of PTx. Most of the participants who performed the Direct method observed cytotoxic effects in wells with diluted vaccine. All laboratories that performed the Indirect method produced interpretable results and while there was some variation, the majority of assays were able to identify vaccines spiked with $1-4 \mathrm{IU} / \mathrm{mL}[112,120]$.

One of the main advantages associated with the $\mathrm{CHO}$ cell clustering assay is that it captures the cell binding, translocation and enzymatic activity of the toxin and therefore is comparable to HIST [110,116]. It is also very sensitive and detects lower levels of pure PTx than HIST [121]. However, there are several disadvantages associated with the different forms of $\mathrm{CHO}$ cell clustering assays. Firstly, it is a subjective decision by the operator to identify when cells are exhibiting a clustering morphology and hence determine the cut-off titre which is the final readout of the assay. This subjectivity results in a great deal of variability [122]. It is for this reason, two operators are required in the standardised methods to read the plates and determine the final titres at which clustering is observed and recorded [103,123]. There is also concern with the Indirect method that any residual PTx activity in the supernatant is not measured in this assay however it could be monitored using alternatives in vitro assays such as carbohydrate binding or ADP-ribosylation [112]. Also, there have been reports that the CHO cell clustering assay failed detect reversion to toxicity of a batch of ACV that failed in the HIST assay. It also failed to detect activity in toxoids that demonstrated some toxicity in the HIST assay [124].

Reference preparations of active PTx with assigned potency values are required as controls in both HIST and CHO assays. They are also important for inter-assay and inter-laboratory comparability. Recently, the standardised CHO cell clustering method was used in the calibration of the current WHO International Standard for PTx (NIBSC code 15/126) and to calibrate EDQM's Biological Reference Preparation (BRP) batch 1 in a joint study $[103,123]$. This study found that the biological activity measured by the $\mathrm{CHO}$ cell assay does not always correspond to the activity found in HIST when different PTx reference preparations are compared. When the first WHO International Standard (IS) for PTx (JNIH-5) was established it was found that the activities in the lethal HIST and CHO assays relative 
to other PTx preparations were approximately the same and therefore the standard was assigned a unitage of 10,000 IU/ampoule for both assays [104,121]. However, when the replacement for JNIH-5 was being established it was found that the activity of the replacement, 15/126, was approximately one fifth of JNIH-5 in the lethal HIST assay but $1 / 15$ the activity of JNIH-5 in the CHO cell assay [103]. A similar discrepancy was observed to BRP batch 1 in both assays [105,123]. The discrepancy between the HIST and CHO assays is probably not unexpected as the activity of biological substances depends on their interaction with the test systems and in the case of two different materials the tests may favour the activity of either one or other of the material [125].

\subsection{Biochemical Assays}

Cyr et al. (2001) first developed an assay to measure the enzymatic activity of the A subunit of PTx [126]. In this assay the ADP-ribosylation activity is measured using a synthetic homologue of a G-protein which is tagged with a fluorescent marker. In the presence of nicotinamide adenine dinucleotide (NAD) the A-subunit of PTx transfers the ADP-ribose of the NAD to the cysteine moiety of the synthetic protein. This ADP-ribosylated product can then be separated from the substrate using reverse-phase HPLC and a fluorescent detector. It has been found that the response is linear for native pure PTx at concentrations ranging from 0.0625 to $4.0 \mu \mathrm{g} / \mathrm{mL}$ [126]. The concentrations of some components of the assay were then slightly modified to assist with the successful method transfer between laboratories [127]. It was then used in an international collaborative study for the establishment of an EDQM PTx BRP [128]. It was during this, and subsequent studies, that it was observed that the ADP-ribosylation activity did not always correlate with residual PTx activity found by HIST in vaccine products $[128,129]$. It was also found that different ACV products had different amounts of ADP-ribosylation activity and a level that would be significant in comparison to the HIST could not be defined. Different detoxification methods as well as different final vaccine formulations may result in this lack of correlation between ADP-ribosylation and HIST. Therefore, it was clear that relying solely on ADP-ribosylation activity may not fully reflect what is observed in the HIST for chemically detoxified products as cell binding and internalisation are required for subsequent ADP-ribosylation to occur [129]. To overcome this limitation a test was developed which measures the activity of the B-subunit [130].

Since the B-oligomer of PTx is associated with binding to carbohydrate on the target cell, an assay was developed to measure this binding activity of PTx to attempt to complement the ADP-ribosylation assay [130,131]. The ELISA based method initially looked at the ability of PTx to bind to plates coated with different glycoproteins or defined oligosaccharides. It was found that PTx bound preferentially to multiantennary $N$-glycans, especially fully sialylated structures such as fetuin. Pertussis toxoid lost the ability to bind to these structures [130]. It was found following validation that this biochemical assay system, comprising both the ADP-ribosylation test and carbohydrate binding assay, correlated with activity in the temperature HIST for 76 batches of seven different ACV products [132]. Subsequently, on behalf of $\mathrm{WHO}$, an international collaborative study using three different commercially available types of ACV products showed that the biochemical assay system, was transferable between laboratories and was suitable for the three types of ACV products included in the study. The residual PTx activity of the three ACV products were different but had the same rank order in the in vitro assay system and the in vivo HIST [133]. This in vitro assay system was included as a potential alternative to HIST in "WHO Recommendations to Assure the Quality, Safety and Efficacy of Acellular Pertussis Vaccines" [92]. It could also be used to characterise PTd prepared by different chemical detoxification processes indicating its potential use for in-process control [134]. Nevertheless, the adoption of this assay system was limited due to two main criticisms: (a) this assay system does not measure all of the mechanisms required for PTx toxicity, such as translocation across the cell membrane, and (b) the assay system's sensitivity has not been fully demonstrated using vaccines spiked with known concentrations of PTx as attempts to do so were not completely satisfactory for the ADP-ribosylation assay $[135,136]$. However, the carbohydrate-binding activity of PTx and different PTd products 
correlates with the rate of translocation into $\mathrm{CHO}$ cells using confocal microscopy with indirect immunofluorescence detection. This indicates that the carbohydrate binding activity could reflect the degree of translocation/internalization activity of PTx and PTd [77]. Furthermore, in a separate in vivo study using mouse footpad swelling model, carbohydrate binding activity in ACVs showed a positive relationship with the severity of local reactions after booster vaccination [137]. This again emphasises the important function of the B-oligomer and as an important determinant for PTx toxicity. As part of the EDQM BSP114 study the spiked vaccines included in the study to evaluate the $\mathrm{CHO}$ assays were also analysed by one participant in the biochemical assays. It was found that dose dependent results were observed for all spiked vaccines and that diluting the samples improved the overall results. The ADP-ribosylation activities of spiked vaccines was not statistically different from unspiked samples and this may be due to the high baseline ADP-ribosylation activity of some ACV products [112]. However, with appropriate assay criteria, both methods could be used to monitor product consistency during and after production [136].

\subsection{Leukocytosis Promotion (LP) Test}

Pertussis infection induces the production of large numbers of white blood cells (leukocytes) in humans, especially infants, and this is associated with poor clinical outcomes [138]. It was through studying the induction of leucocytosis in mice by WCV and bacterial culture supernatants that pertussis lymphocytosis-promoting factor (LPF) was first identified and purified. The LPF was subsequently identified and renamed as PTx [138-141]. The promotion of leukocytosis in the peripheral blood of mice can be used to determine any PTx activity in test samples by comparing the number of circulating leukocytes from mice injected with the test samples to those that receive control samples. The number of circulating leukocytes can be measured microscopically using a haemocytometer or an automated system such as a Coulter Counter [142]. The mean number of leukocytes three days after injection should not exceed 10 times the number before injection [143]. As with HIST there are many variable parameters associated with this test such as the route of administration (subcutaneous, intraperitoneal or intravenous), the number of days after injection in which the blood samples are (usually 3-6 days) and the number of mice per group. In a multi-laboratory study it was found that the LP test performed better than HIST and CHO in identifying three WCV products with high toxicity [142]. Although the LP test is included in the WHO Manual for the control of WCV combination vaccines it is not in the Recommendations to assure the quality, safety and potency of acellular pertussis vaccines [92,144]. There are several disadvantages associated with this method. Firstly, it is animal based and therefore there are ethical concerns about its use to measure PTx in vaccines. Like HIST the exact mechanism in which PTx causes the increase in white blood cells is unclear and there is a high degree of interlaboratory variability due to a lack of standardisation despite attempts to introduce harmonisation $[138,142,145]$.

\subsection{Other Cell-Based Assays}

Since the ADP-ribosylation activity of PTx causes an increase in cellular cAMP in CHO cells along with clustering it may be possible to measure it to produce a more definitive quantitative estimate of PTx activity without the subjectivity of deciding when cells exhibit a clustering morphology. Hoonakker et al. have developed such an assay. Initially they used A10 cells and monitored the effect of PTx on the cells by measuring the intracellular levels of cAMP. This method could detect PTx activity, but it lacked sensitivity and robustness [146]. They improved the system by using novel reporter cell lines (CHO-CRE and A10-CRE) that stably express a reporter construct that is responsive to cAMP levels. Both cell lines can detect PTx in a concentration-dependent manner but only the CHO-CRE cell line can detect PTx in a multivalent vaccine matrix at levels similar to HIST [147]. The sensitivity of this method has been reported as $0.2 \mathrm{IU} / \mathrm{mL}$ for pure PTx [112]. The CHO-CRE (CHO-cAMP-PTx reporter cell assay) based method was used in the collaborative study for the establishment of the WHO 2nd IS for PTx and the activity of the new standard relative to the 1st IS was comparable to the results observed by participants that performed the standardised $\mathrm{CHO}$ cell clustering assay [103]. This 
indicates that it produces results similar to the $\mathrm{CHO}$ clustering assay and therefore has the potential to be a less subjective cell-based assay, but vaccine adjuvant associated cytotoxicity may also present a problem.

The cell clustering and changes in cAMP levels observed in the cell-based assays discussed previously are associated with the ADP-ribosylation activity of PTx following its binding to the cells and subsequent internalisation. While the ADP-ribosylation pathway is clinically important it may not be the only physiological effect of PTx and the B-subunit has been shown to induce an ADP-ribosylation independent pathway on its own. However, the two pathways differ in that ADP-ribosylation occurs more rapidly and at much lower concentrations of PTx than the ADP-ribosylation independent pathway [148]. Therefore, several studies have used gene expression profiling of human cell lines and animals exposed to PTx by DNA microarray as a way to determine all aspects of PTx activity. Through these methods a number of possible biomarkers for toxin activity have been identified [143,148-150]. These studies may further improve the understanding of PTx toxicity and lead to more accurate assays.

\section{Discussion and Conclusions}

Due to recent outbreaks of pertussis infection, there is a continued interest in, and an urgent need for, the development of new and improved ACV vaccines. Ideally these will induce longer lasting, more cell-based immunity as well as reducing transmission of infection to offer the potential for herd protection. There may also be WCV products developed that have reduced toxicity. Therefore, methods to measure PTx activity continue to be required to support the development and production of new vaccines.

There are many challenges in measuring residual PTx activity in ACVs. These include the diversity of vaccine preparations, differences in pertussis antigen composition and detoxification methods. Also, various purification processes and formulations are used. The basis of the current regulatory approaches for testing residual activity is to show consistency with clinical lots or equivalents. However, a precise quantitative assay would be preferable to a limit test. For the characterisation of new products and formulations or for performing pre-clinical evaluation, any assay method that is validated and optimised for use should use a stable reference toxin calibrated in terms of bioactivity (IU) to allow calculation of relative activity. Inclusion of such a reference toxin will help to define assay sensitivity and to express results in IU with traceability to IS. Assay sensitivity can be established with spiking experiments to show that the assay can detect a defined amount of spiking dose (e.g., 2IU) and the activity limits for this spiking dose should be defined during validation stage. Routine assays should include the spiking dose and the activity should fall within the pre-defined limits and included as one of the validity criteria. The chosen assay should establish limits for the 'safe' amount of PTx activity in IU based on a panel of products with a known history of safety. Assays should define an upper limit for residual active PTx. Manufacturers will need to prove that the chosen method is effective to measure residual PTx activity in their product as optimisation maybe required for their specific products. Ideally any assay for measuring PTx activity will be in vitro based and have the same sensitivity as HIST. This would reduce the number of animals used in the production of ACVs.

There are a number of stable PTx references available from the WHO (NIBSC code: 15/126) and EDQM (Catalogue No. Y0000021) which have been calibrated in IU for HIST (lethal method) and the standardised $\mathrm{CHO}$ cell-clustering assay.

All the methods described in this review can detect levels of PTx activity associated with safe vaccine products. Once optimised and validated, they, all have the potential to assess residual and reversion to toxicity. Assays may also require vaccine specific modifications for final product testing due to the potential interference by adjuvants or excipients. These modifications may include diluting the vaccines to overcome cytotoxic adjuvant, testing only vaccine pellets as opposed to the complete formulation and/or desorbing antigens from adjuvants. Specificity and detection limits are very important for any methods to be considered suitable for measuring PTx activity in ACVs. Due to the disadvantages and ethical concerns associated with HIST, and animal use in general, it is important 
that alternative methods used to measure PTx activity should be based on in vitro technology. All the methods mentioned here have their advantages and disadvantages. The ideal in vitro assay would measure all the steps in PTx toxicity (carbohydrate binding, translocation and ADP-ribosylation activity) and be suitable for the final formulation of the vaccine in the presence of adjuvants. Due to the high degree of variability and methods of HIST it may not be possible to find a correlation between it and an in vitro alternative. The question of validation of alternatives to HIST have been discussed elsewhere [93].

The recent decision to remove the requirement for testing for residual and reversion to toxicity in final formulated vaccines from the European Pharmacopoeia once the detoxification process has been demonstrated to be stable means that not only does HIST not have to be performed on final formulations but none of the in vitro methods considered as alternatives to HIST are required [106]. The activity of purified PTx and later the PTd will be determined upstream by the manufacturer using a CHO cell clustering-based assay. This will lead to a reduction in the use of animals in countries and for well-established products where testing adheres to the European Pharmacopoeia guidance. Tests for residual toxicity and reversion to toxicity will still be required for new products, ideally these will be validated in vitro assays, but in vivo tests may be necessary.

Furthermore, considering the fact that the majority of ACV products currently used globally are long established, it may be possible for other regulatory authorities to follow the example of the EDQM and remove the requirements for testing for residual and reversion to toxicity from final products once they are satisfied that the detoxification is robust. While this too would reduce the numbers of mice used in testing there always remains the possibility to use validated in vitro methods to monitor consistency of final products if evidence suggests that it is required.

Author Contributions: Conceptualization, K.M., C.A. and I.F.; writing-original draft preparation, K.M.; writing-review and editing, K.M., C.A. and I.F.

Funding: This research received no external funding.

Conflicts of Interest: The authors declare no conflict of interest.

\section{References}

1. Melvin, J.A.; Scheller, E.V.; Miller, J.F.; Cotter, P.A. Bordetella pertussis pathogenesis: Current and future challenges. Nat. Rev. Microbiol. 2014, 12, 274-288. [CrossRef] [PubMed]

2. Pertussis vaccines: WHO position paper. Wkly. Epidemiol. Rec. 2010, 85, 385-400.

3. Dorji, D.; Mooi, F.; Yantorno, O.; Deora, R.; Graham, R.M.; Mukkur, T.K. Bordetella pertussis virulence factors in the continuing evolution of whooping cough vaccines for improved performance. Med. Microbiol. Immunol. 2017, 207, 3-26. [CrossRef] [PubMed]

4. Corbel, M.J.; Xing, D.K. Toxicity and potency evaluation of pertussis vaccines. Expert Rev. Vaccines 2004, 3, 89-101. [CrossRef] [PubMed]

5. Higgs, R.; Higgins, S.C.; Ross, P.J.; Mills, K.H. Immunity to the respiratory pathogen Bordetella pertussis. Mucosal Immunol. 2012, 5, 485-500. [CrossRef]

6. Kilgore, P.E.; Salim, A.M.; Zervos, M.J.; Schmitt, H.J. Pertussis: Microbiology, Disease, Treatment, and Prevention. Clin. Microbiol. Rev. 2016, 29, 449-486. [CrossRef] [PubMed]

7. Mattoo, S.; Foreman-Wykert, A.K.; Cotter, P.A.; Miller, J.F. Mechanisms of Bordetella pathogenesis. Front. Biosci. 2001, 6, E168-E186. [CrossRef]

8. Chen, Q.; Stibitz, S. The BvgASR virulence regulon of Bordetella pertussis. Curr. Opin. Microbiol. 2019, 47, 74-81. [CrossRef]

9. Bisgard, K.M.; Rhodes, P.; Connelly, B.L.; Bi, D.; Hahn, C.; Patrick, S.; Glode, M.P.; Ehresmann, K.R. Pertussis vaccine effectiveness among children 6 to 59 months of age in the United States, 1998-2001. Pediatrics 2005, 116, e285-e294. [CrossRef]

10. Xu, Y.; Tan, Y.; Asokanathan, C.; Zhang, S.; Xing, D.; Wang, J. Characterization of co-purified acellular pertussis vaccines. Hum. Vaccin. Immunother. 2015, 11, 421-427. [CrossRef] 
11. Tan, T.; Dalby, T.; Forsyth, K.; Halperin, S.A.; Heininger, U.; Hozbor, D.; Plotkin, S.; Ulloa-Gutierrez, R.; Wirsing von Konig, C.H. Pertussis Across the Globe: Recent Epidemiologic Trends From 2000 to 2013. Pediatric Infect. Dis. J. 2015, 34, e222-e232. [CrossRef] [PubMed]

12. Dias, W.O.; Van der Ark, A.A.; Sakauchi, M.A.; Kubrusly, F.S.; Prestes, A.F.; Borges, M.M.; Furuyama, N.; Horton, D.S.; Quintilio, W.; Antoniazi, M.; et al. An improved whole cell pertussis vaccine with reduced content of endotoxin. Hum. Vaccin. Immunother. 2013, 9, 339-348. [CrossRef] [PubMed]

13. Locht, C. Will we have new pertussis vaccines? Vaccine 2018, 36, 5460-5469. [CrossRef] [PubMed]

14. Warfel, J.M.; Zimmerman, L.I.; Merkel, T.J. Acellular pertussis vaccines protect against disease but fail to prevent infection and transmission in a nonhuman primate model. Proc. Natl. Acad. Sci. USA 2014, 111, 787-792. [CrossRef] [PubMed]

15. Barlow, W.E.; Davis, R.L.; Glasser, J.W.; Rhodes, P.H.; Thompson, R.S.; Mullooly, J.P.; Black, S.B.; Shinefield, H.R.; Ward, J.I.; Marcy, S.M.; et al. The risk of seizures after receipt of whole-cell pertussis or measles, mumps, and rubella vaccine. N. Engl. J. Med. 2001, 345, 656-661. [CrossRef] [PubMed]

16. Olin, P.; Rasmussen, F.; Gustafsson, L.; Hallander, H.O.; Heijbel, H. Randomised controlled trial of two-component, three-component, and five-component acellular pertussis vaccines compared with whole-cell pertussis vaccine. Ad Hoc Group for the Study of Pertussis Vaccines. Lancet 1997, 350, 1569-1577. [CrossRef]

17. Cherry, J.D. Historical review of pertussis and the classical vaccine. J. Infect. Dis. 1996, 174, S259-S263. [CrossRef] [PubMed]

18. Gustafsson, L.; Hallander, H.O.; Olin, P.; Reizenstein, E.; Storsaeter, J. A controlled trial of a two-component acellular, a five-component acellular, and a whole-cell pertussis vaccine. N. Engl. J. Med. 1996, 334, 349-355. [CrossRef] [PubMed]

19. Gangarosa, E.J.; Galazka, A.M.; Wolfe, C.R.; Phillips, L.M.; Gangarosa, R.E.; Miller, E.; Chen, R.T. Impact of anti-vaccine movements on pertussis control: The untold story. Lancet 1998, 351, 356-361. [CrossRef]

20. Klein, N.P. Licensed pertussis vaccines in the United States. History and current state. Hum. Vaccin. Immunother. 2014, 10, 2684-2690. [CrossRef] [PubMed]

21. Sato, Y.; Kimura, M.; Fukumi, H. Development of a pertussis component vaccine in Japan. Lancet 1984, 1, 122-126. [CrossRef]

22. Kuchar, E.; Karlikowska-Skwarnik, M.; Han, S.; Nitsch-Osuch, A. Pertussis: History of the Disease and Current Prevention Failure. Adv. Exp. Med. Biol. 2016, 934, 77-82. [CrossRef] [PubMed]

23. Sato, Y.; Sato, H. Development of acellular pertussis vaccines. Biologicals 1999, 27, 61-69. [CrossRef] [PubMed]

24. Edwards, K.M.; Karzon, D.T. Pertussis vaccines. Pediatric Clin. N. Am. 1990, 37, 549-566. [CrossRef]

25. Rappuoli, R.; Podda, A.; Pizza, M.; Covacci, A.; Bartoloni, A.; De Magistris, M.T.; Nencioni, L. Progress towards the development of new vaccines against whooping cough. Vaccine 1992, 10, 1027-1032. [CrossRef]

26. Storsaeter, J.; Hallander, H.O.; Gustafsson, L.; Olin, P. Levels of anti-pertussis antibodies related to protection after household exposure to Bordetella pertussis. Vaccine 1998, 16, 1907-1916. [CrossRef]

27. Pierce, V.M.; Vazquez, M. New combination vaccines: Integration into pediatric practice. Pediatric Infect. Dis. J. 2007, 26, 1149-1150. [CrossRef]

28. Pines, E.; Barrand, M.; Fabre, P.; Salomon, H.; Blondeau, C.; Wood, S.C.; Hoffenbach, A. New acellular pertussis-containing paediatric combined vaccines. Vaccine 1999, 17, 1650-1656. [CrossRef]

29. Vidor, E.; Soubeyrand, B. Manufacturing DTaP-based combination vaccines: Industrial challenges around essential public health tools. Expert Rev. Vaccines 2016, 15, 1575-1582. [CrossRef]

30. Burns, D.L.; Meade, B.D.; Messionnier, N.E. Pertussis resurgence: Perspectives from the Working Group Meeting on pertussis on the causes, possible paths forward, and gaps in our knowledge. J. Infect. Dis. 2014, 209, S32-S35. [CrossRef]

31. Campbell, P.; McIntyre, P.; Quinn, H.; Hueston, L.; Gilbert, G.L.; McVernon, J. Increased population prevalence of low pertussis toxin antibody levels in young children preceding a record pertussis epidemic in Australia. PLoS ONE 2012, 7, e35874. [CrossRef] [PubMed]

32. De Greeff, S.C.; De Melker, H.E.; Van Gageldonk, P.G.; Schellekens, J.F.; Van der Klis, F.R.; Mollema, L.; Mooi, F.R.; Berbers, G.A. Seroprevalence of pertussis in The Netherlands: Evidence for increased circulation of Bordetella pertussis. PLoS ONE 2010, 5, e14183. [CrossRef] [PubMed]

33. Campbell, H.; Amirthalingam, G.; Andrews, N.; Fry, N.K.; George, R.C.; Harrison, T.G.; Miller, E. Accelerating control of pertussis in England and Wales. Emerg. Infect. Dis. 2012, 18, 38-47. [CrossRef] [PubMed] 
34. Choi, Y.H.; Campbell, H.; Amirthalingam, G.; Van Hoek, A.J.; Miller, E. Investigating the pertussis resurgence in England and Wales, and options for future control. BMC Med. 2016, 14, 121. [CrossRef] [PubMed]

35. Winter, K.; Glaser, C.; Watt, J.; Harriman, K. Pertussis epidemic-California, 2014. MMWR. Morb. Mortal. Wkly. Rep. 2014, 63, 1129-1132. [PubMed]

36. Barret, A.S.; Ryan, A.; Breslin, A.; Cullen, L.; Murray, A.; Grogan, J.; Bourke, S.; Cotter, S. Pertussis outbreak in northwest Ireland, January-June 2010. Eurosurveillance 2010, 15, 19654. [PubMed]

37. Loconsole, D.; De Robertis, A.L.; Morea, A.; Metallo, A.; Lopalco, P.L.; Chironna, M. Resurgence of Pertussis and Emergence of the Ptxp3 Toxin Promoter Allele in South Italy. Pediatric Infect. Dis. J. 2018, 37, e126-e131. [CrossRef]

38. Winter, K.; Zipprich, J.; Harriman, K. Pertussis in California: A Tale of 2 Epidemics. Pediatric Infect. Dis. J. 2018, 37, 324-328. [CrossRef]

39. Brummelman, J.; Helm, K.; Hamstra, H.J.; Van der Ley, P.; Boog, C.J.; Han, W.G.; Van Els, C.A. Modulation of the CD4(+) T cell response after acellular pertussis vaccination in the presence of TLR4 ligation. Vaccine 2015, 33, 1483-1491. [CrossRef]

40. Ross, P.J.; Sutton, C.E.; Higgins, S.; Allen, A.C.; Walsh, K.; Misiak, A.; Lavelle, E.C.; McLoughlin, R.M.; Mills, K.H. Relative contribution of Th1 and Th17 cells in adaptive immunity to Bordetella pertussis: Towards the rational design of an improved acellular pertussis vaccine. PLoS Pathog. 2013, 9, e1003264. [CrossRef]

41. Dunne, A.; Mielke, L.A.; Allen, A.C.; Sutton, C.E.; Higgs, R.; Cunningham, C.C.; Higgins, S.C.; Mills, K.H. A novel TLR2 agonist from Bordetella pertussis is a potent adjuvant that promotes protective immunity with an acellular pertussis vaccine. Mucosal Immunol. 2015, 8, 607-617. [CrossRef] [PubMed]

42. Gustafsson, L.; Hessel, L.; Storsaeter, J.; Olin, P. Long-term follow-up of Swedish children vaccinated with acellular pertussis vaccines at 3,5, and 12 months of age indicates the need for a booster dose at 5 to 7 years of age. Pediatrics 2006, 118, 978-984. [CrossRef]

43. Olin, P.; Gustafsson, L.; Barreto, L.; Hessel, L.; Mast, T.C.; Rie, A.V.; Bogaerts, H.; Storsaeter, J. Declining pertussis incidence in Sweden following the introduction of acellular pertussis vaccine. Vaccine 2003, 21, 2015-2021. [CrossRef]

44. Barkoff, A.M.; Mertsola, J.; Pierard, D.; Dalby, T.; Hoegh, S.V.; Guillot, S.; Stefanelli, P.; Van Gent, M.; Berbers, G.; Vestrheim, D.; et al. Pertactin-deficient Bordetella pertussis isolates: Evidence of increased circulation in Europe, 1998 to 2015. Eurosurveillance 2019, 24, 1700832. [CrossRef] [PubMed]

45. Hegerle, N.; Dore, G.; Guiso, N. Pertactin deficient Bordetella pertussis present a better fitness in mice immunized with an acellular pertussis vaccine. Vaccine 2014, 32, 6597-6600. [CrossRef] [PubMed]

46. Williams, M.M.; Sen, K.; Weigand, M.R.; Skoff, T.H.; Cunningham, V.A.; Halse, T.A.; Tondella, M.L. Bordetella pertussis Strain Lacking Pertactin and Pertussis Toxin. Emerg. Infect. Dis. 2016, 22, 319-322. [CrossRef] [PubMed]

47. Mooi, F.R.; Van Der Maas, N.A.; De Melker, H.E. Pertussis resurgence: Waning immunity and pathogen adaptation-Two sides of the same coin. Epidemiol. Infect. 2014, 142, 685-694. [CrossRef] [PubMed]

48. Bouchez, V.; Brun, D.; Cantinelli, T.; Dore, G.; Njamkepo, E.; Guiso, N. First report and detailed characterization of B. pertussis isolates not expressing Pertussis Toxin or Pertactin. Vaccine 2009, 27, 6034-6041. [CrossRef]

49. Bouchez, V.; Hegerle, N.; Strati, F.; Njamkepo, E.; Guiso, N. New Data on Vaccine Antigen Deficient Bordetella pertussis Isolates. Vaccines 2015, 3, 751-770. [CrossRef]

50. Berbers, G.A.; De Greeff, S.C.; Mooi, F.R. Improving pertussis vaccination. Hum. Vaccines 2009, 5, 497-503. [CrossRef]

51. Crowcroft, N.S.; Pebody, R.G. Recent developments in pertussis. Lancet 2006, 367, 1926-1936. [CrossRef]

52. Kitchin, N.R. Review of diphtheria, tetanus and pertussis vaccines in clinical development. Expert Rev. Vaccines 2011, 10, 605-615. [CrossRef] [PubMed]

53. Gaillard, M.E.; Bottero, D.; Errea, A.; Ormazabal, M.; Zurita, M.E.; Moreno, G.; Rumbo, M.; Castuma, C.; Bartel, E.; Flores, D.; et al. Acellular pertussis vaccine based on outer membrane vesicles capable of conferring both long-lasting immunity and protection against different strain genotypes. Vaccine 2014, 32, 931-937. [CrossRef] [PubMed]

54. Locht, C.; Coutte, L.; Mielcarek, N. The ins and outs of pertussis toxin. FEBS J. 2011, 278, 4668-4682. [CrossRef] [PubMed]

55. Sekura, R.D.; Fish, F.; Manclark, C.R.; Meade, B.; Zhang, Y.L. Pertussis toxin. Affinity purification of a new ADP-ribosyltransferase. J. Biol. Chem. 1983, 258, 14647-14651. [PubMed] 
56. Tamura, M.; Nogimori, K.; Murai, S.; Yajima, M.; Ito, K.; Katada, T.; Ui, M.; Ishii, S. Subunit structure of islet-activating protein, pertussis toxin, in conformity with the A-B model. Biochemistry 1982, 21, 5516-5522. [CrossRef]

57. Tamura, M.; Nogimori, K.; Yajima, M.; Ase, K.; Ui, M. A role of the B-oligomer moiety of islet-activating protein, pertussis toxin, in development of the biological effects on intact cells. J. Biol. Chem. 1983, 258, 6756-6761.

58. Ui, M. ADP-ribosylating Toxins and G protein; Moss, J., Vaughan, M., Eds.; American Society for Microbiology: Washington, DC, USA, 1990.

59. Title 21. Pertussis vaccine 620.1. In US Code of Federal Regulations; Government Printing Office: Washington, DC, USA, 1983; pp. 58-61.

60. El Baya, A.; Linnermann, R.; Von Olleschik-Elbheim, L.; Schmidt, M.A. Pertussis toxin. Entry into cells and enzymatic activity. Adv. Exp. Med. Biol. 1997, 419, 83-86.

61. Banerjee, T.; Cilenti, L.; Taylor, M.; Showman, A.; Tatulian, S.A.; Teter, K. Thermal Unfolding of the Pertussis Toxin S1 Subunit Facilitates Toxin Translocation to the Cytosol by the Mechanism of Endoplasmic Reticulum-Associated Degradation. Infect. Immun. 2016, 84, 3388-3398. [CrossRef]

62. Plaut, R.D.; Carbonetti, N.H. Retrograde transport of pertussis toxin in the mammalian cell. Cell. Microbiol. 2008, 10, 1130-1139. [CrossRef]

63. Bokoch, G.M.; Katada, T.; Northup, J.K.; Hewlett, E.L.; Gilman, A.G. Identification of the predominant substrate for ADP-ribosylation by islet activating protein. J. Biol. Chem. 1983, 258, 2072-2075. [PubMed]

64. Katada, T.; Ui, M. Direct modification of the membrane adenylate cyclase system by islet-activating protein due to ADP-ribosylation of a membrane protein. Proc. Natl. Acad. Sci. USA 1982, 79, 3129-3133. [CrossRef] [PubMed]

65. Katada, T.; Ui, M. ADP ribosylation of the specific membrane protein of C6 cells by islet-activating protein associated with modification of adenylate cyclase activity. J. Biol. Chem. 1982, 257, 7210-7216. [PubMed]

66. Munoz, J. Biological activities of pertussigen (pertussis toxin). In Pertussis Toxin; Sekura, R., Moss, J., Vaughan, M., Eds.; Academic Press Inc.: London, UK, 1985.

67. Oh, H.; Kim, B.G.; Nam, K.T.; Hong, S.H.; Ahn, D.H.; Choi, G.S.; Kim, H.; Hong, J.T.; Ahn, B.Y. Characterization of the carbohydrate binding and ADP-ribosyltransferase activities of chemically detoxified pertussis toxins. Vaccine 2013, 31, 2988-2993. [CrossRef]

68. Blatter, M.; Friedland, L.R.; Weston, W.M.; Li, P.; Howe, B. Immunogenicity and safety of a tetanus toxoid, reduced diphtheria toxoid and three-component acellular pertussis vaccine in adults 19-64 years of age. Vaccine 2009, 27, 765-772. [CrossRef] [PubMed]

69. Thierry-Carstensen, B.; Dalby, T.; Stevner, M.A.; Robbins, J.B.; Schneerson, R.; Trollfors, B. Experience with monocomponent acellular pertussis combination vaccines for infants, children, adolescents and adults-A review of safety, immunogenicity, efficacy and effectiveness studies and 15 years of field experience. Vaccine 2013, 31, 5178-5191. [CrossRef] [PubMed]

70. Thierry-Carstensen, B.; Jordan, K.; Uhlving, H.H.; Dalby, T.; Sorensen, C.; Jensen, A.M.; Heilmann, C. A randomised, double-blind, non-inferiority clinical trial on the safety and immunogenicity of a tetanus, diphtheria and monocomponent acellular pertussis (TdaP) vaccine in comparison to a tetanus and diphtheria (Td) vaccine when given as booster vaccinations to healthy adults. Vaccine 2012, 30, 5464-5471. [CrossRef]

71. Fowler, S.; Byron, O.; Jumel, K.; Xing, D.; Corbel, M.J.; Bolgiano, B. Novel configurations of high molecular weight species of the pertussis toxin vaccine component. Vaccine 2003, 21, 2678-2688. [CrossRef]

72. Fowler, S.; Xing, D.K.; Bolgiano, B.; Yuen, C.T.; Corbel, M.J. Modifications of the catalytic and binding subunits of pertussis toxin by formaldehyde: Effects on toxicity and immunogenicity. Vaccine 2003, 21, 2329-2337. [CrossRef]

73. Habeeb, A.J.; Hiramoto, R. Reaction of proteins with glutaraldehyde. Arch. Biochem. Biophys. 1968, 126, 16-26. [CrossRef]

74. Ibsen, P.H. The effect of formaldehyde, hydrogen peroxide and genetic detoxification of pertussis toxin on epitope recognition by murine monoclonal antibodies. Vaccine 1996, 14, 359-368. [CrossRef]

75. Metz, B.; Kersten, G.F.; Hoogerhout, P.; Brugghe, H.F.; Timmermans, H.A.; De Jong, A.; Meiring, H.; Ten Hove, J.; Hennink, W.E.; Crommelin, D.J.; et al. Identification of formaldehyde-induced modifications in proteins: Reactions with model peptides. J. Biol. Chem. 2004, 279, 6235-6243. [CrossRef] [PubMed] 
76. Nogimori, K.; Ito, K.; Tamura, M.; Satoh, S.; Ishii, S.; Ui, M. Chemical modification of islet-activating protein, pertussis toxin. Essential role of free amino groups in its lymphocytosis-promoting activity. Biochim. Biophys. Acta 1984, 801, 220-231. [CrossRef]

77. Tan, Y.; Fleck, R.A.; Asokanathan, C.; Yuen, C.T.; Xing, D.; Zhang, S.; Wang, J. Confocal microscopy study of pertussis toxin and toxoids on CHO-cells. Hum. Vaccin. Immunother. 2013, 9, 332-338. [CrossRef] [PubMed]

78. Garcia-Sainz, J.A.; Romero-Avila, M.T.; Ruiz-Arriaga, A.; Ruiz-Puente, J.; Agundis, C.; Ortiz, V.; Isibasi, A. Characterization and detoxification of an easily prepared acellular pertussis vaccine. Antigenic role of the A protomer of pertussis toxin. Vaccine 1992, 10, 341-344. [CrossRef]

79. Nicosia, A.; Perugini, M.; Franzini, C.; Casagli, M.C.; Borri, M.G.; Antoni, G.; Almoni, M.; Neri, P.; Ratti, G.; Rappuoli, R. Cloning and sequencing of the pertussis toxin genes: Operon structure and gene duplication. Proc. Natl. Acad. Sci. USA 1986, 83, 4631-4635. [CrossRef] [PubMed]

80. Sutherland, J.N.; Chang, C.; Yoder, S.M.; Rock, M.T.; Maynard, J.A. Antibodies recognizing protective pertussis toxin epitopes are preferentially elicited by natural infection versus acellular immunization. Clin. Vaccine Immunol. 2011, 18, 954-962. [CrossRef] [PubMed]

81. Rappuoli, R. Toxin inactivation and antigen stabilization: Two different uses of formaldehyde. Vaccine 1994, 12, 579-581. [CrossRef]

82. Seubert, A.; D’Oro, U.; Scarselli, M.; Pizza, M. Genetically detoxified pertussis toxin (PT-9K/129G): Implications for immunization and vaccines. Expert Rev. Vaccines 2014, 13, 1191-1204. [CrossRef]

83. Surendran, N.; Pichichero, M. Genetically detoxified pertussis toxin induces superior antigen specific CD4 T cell responses compared to chemically detoxified pertussis toxin. Hum. Vaccin. Immunother. 2019, 15, 1167-1170. [CrossRef]

84. Xing, D.; Canthaboo, C.; Douglas-Bardsley, A.; Yuen, C.T.; Prior, S.; Liu, Y.; Corbel, M. Developments in reduction and replacement of in vivo toxicity and potency tests for pertussis vaccines. Dev. Biol. 2002, 111, $57-68$.

85. Blanchard Rohner, G.; Chatzis, O.; Chinwangso, P.; Rohr, M.; Grillet, S.; Salomon, C.; Lemaitre, B.; Boonrak, P.; Lawpoolsri, S.; Clutterbuck, E.; et al. Boosting Teenagers with Acellular Pertussis Vaccines Containing Recombinant or Chemically Inactivated Pertussis Toxin: A Randomized Clinical Trial. Clin. Infect. Dis. 2018, 68, 1213-1222. [CrossRef] [PubMed]

86. Pitisuttithum, P.; Chokephaibulkit, K.; Sirivichayakul, C.; Sricharoenchai, S.; Dhitavat, J.; Pitisuthitham, A.; Phongsamart, W.; Boonnak, K.; Lapphra, K.; Sabmee, Y.; et al. Antibody persistence after vaccination of adolescents with monovalent and combined acellular pertussis vaccines containing genetically inactivated pertussis toxin: A phase 2/3 randomised, controlled, non-inferiority trial. Lancet Infect. Dis. 2018, 18, 1260-1268. [CrossRef]

87. Sirivichayakul, C.; Chanthavanich, P.; Limkittikul, K.; Siegrist, C.A.; Wijagkanalan, W.; Chinwangso, P.; Petre, J.; Hong Thai, P.; Chauhan, M.; Viviani, S. Safety and immunogenicity of a combined Tetanus, Diphtheria, recombinant acellular Pertussis vaccine (TdaP) in healthy Thai adults. Hum. Vaccin. Immunother. 2017, 13, 136-143. [CrossRef] [PubMed]

88. Buasri, W.; Impoolsup, A.; Boonchird, C.; Luengchaichawange, A.; Prompiboon, P.; Petre, J.; Panbangred, W. Construction of Bordetella pertussis strains with enhanced production of genetically-inactivated Pertussis Toxin and Pertactin by unmarked allelic exchange. BMC Microbiol. 2012, 12, 61. [CrossRef]

89. Zealey, G.R.; Loosmore, S.M.; Yacoob, R.K.; Cockle, S.A.; Herbert, A.B.; Miller, L.D.; Mackay, N.J.; Klein, M.H. Construction of Bordetella pertussis strains that overproduce genetically inactivated pertussis toxin. Appl. Environ. Microbiol. 1992, 58, 208-214.

90. Adsorbed purified pertussis vaccine. In Minimum Requirements for Biological Products; Ministry of Health, Labour and Welfare: Tokyo, Japan, 2006; pp. 150-153.

91. Pertussis vaccine acellular component adsorbed, monograph 1356. In European Pharmacopoeia, 9th ed.; Council of Europe: Strasbourg, France, 2016.

92. WHO Expert Committee on Biological Standardization. Recommendations to assure the quality, safety and efficacy of acellular pertussis vaccines. In WHO Technical Report Series NO. 979; WHO Press: Geneva, Switzerland, 2013; pp. 187-260.

93. Arciniega, J.; Wagner, L.; Prymula, R.; Sebo, P.; Isbrucker, R.; Descampe, B.; Chapsal, J.M.; Costanzo, A.; Hendriksen, C.; Hoonaker, M.; et al. Alternatives to HIST for acellular pertussis vaccines: Progress and challenges in replacement. Pharmeur. Bio Sci. Notes 2016, 2015, 82-96. 
94. Ambrus, J.L.; Packman, E.W.; Rossi, G.V.; Ambrus, C.M.; Harrisson, J.W. The antagonism and synergism of histamine and antihistamines in mice. J. Pharm. Pharmacol. 1952, 4, 466-470. [CrossRef]

95. Kind, L.S. The altered reactivity of mice after inoculation with Bordetella pertussis vaccine. Bacteriol. Rev. 1958, 22, 173-182.

96. Parfentjev, I.A.; Goodline, M.A. Histamine shock in mice sensitized with Hemophilus pertussis vaccine. J. Pharmacol. Exp. Ther. 1948, 92, 411-413.

97. Pittman, M. Determination of the histamine sensitizing unitage of pertussis vaccine. J. Biol. Stand. 1975, 3, 185-191. [CrossRef]

98. Pertussis vaccine acellular co-purified adsorbed, monograph 1595. In European Pharmacopoeia, 9th ed.; Council of Europe: Strasbourg, France, 2016.

99. Ochiai, M.; Yamamoto, A.; Kataoka, M.; Toyoizumi, H.; Arakawa, Y.; Horiuchi, Y. Highly sensitive histamine-sensitization test for residual activity of pertussis toxin in acellular pertussis vaccine. Biologicals 2007, 35, 259-264. [CrossRef] [PubMed]

100. Ishida, S.; Kurokawa, M.; Asakawa, S.; Iwasa, S. A sensitive assay method for the histamine-sensitizing factor using change in rectal temperature of mice after histamine challenge as a response. J. Biol. Stand. 1979, 7, 21-29. [CrossRef]

101. Pertussis vaccine. In Pharmacopoeia of the People's Republic of China (volume III); People's Medical Publishing House: Beijing, China, 2005; pp. 67-71.

102. Hoonakker, M.; Arciniega, J.; Hendriksen, C. Safety testing of acellular pertussis vaccines: Use of animals and 3Rs alternatives. Hum. Vaccin. Immunother. 2017, 13, 2522-2530. [CrossRef] [PubMed]

103. Markey, K.; Asokanathan, C.; Tierney, S.; Hockley, J.; Douglas-Bardsley, A. Collaborative Study: Evaluation of Proposed Second International Standard for Pertussis Toxin Code: 15/126; WHO Press: Geneva, Switzerland, 2017.

104. Xing, D.; Gaines-Das, R.; Newland, P.; Corbel, M. Evaluation of Proposed International Standard of Perussis Toxin Code JNIH-5; WHO Press: Geneva, Switzerland, 2003.

105. Xing, D.; Maes, A.; Behr-Gross, M.E.; Costanzo, A.; Daas, A.; Buchheit, K.H. Collaborative study for the standardisation of the histamine sensitizing test in mice and the $\mathrm{CHO}$ cell-based assay for the residual toxicity testing of acellular pertussis vaccines. Pharmeur. Bio Sci. Notes 2010, 2010, 51-63. [PubMed]

106. European Directorate for the Quality of Medicine. Ph. Eur. to replace Histamine Sensitisation Test (HIST) for Residual Pertussis Toxin Testing. Available online: https://www.edqm.eu/en/news/ph-eur-replace-histaminesensitisation-test-hist-residual-pertussis-toxin-testing (accessed on 10 June 2019).

107. Carbonetti, N.H. Pertussis toxin and adenylate cyclase toxin: Key virulence factors of Bordetella pertussis and cell biology tools. Future Microbiol. 2010, 5, 455-469. [CrossRef] [PubMed]

108. Diehl, S.A.; McElvany, B.; Noubade, R.; Seeberger, N.; Harding, B.; Spach, K.; Teuscher, C. G proteins Galphai1/3 are critical targets for Bordetella pertussis toxin-induced vasoactive amine sensitization. Infect. Immun. 2014, 82, 773-782. [CrossRef] [PubMed]

109. Mangmool, S.; Kurose, H. G(i/o) protein-dependent and -independent actions of Pertussis Toxin (PTX). Toxins 2011, 3, 884-899. [CrossRef] [PubMed]

110. Wagner, L.D.; Corvette, L.J.; Ngundi, M.M.; Burns, D.L. Towards replacement of the acellular pertussis vaccine safety test: Comparison of in vitro cytotoxic activity and in vivo activity in mice. Vaccine 2017, 35, 7160-7165. [CrossRef] [PubMed]

111. Bache, C.; Hoonakker, M.; Hendriksen, C.; Buchheit, K.H.; Spreitzer, I.; Montag, T. Workshop on Animal free Detection of Pertussis Toxin in Vaccines-Alternatives to the Histamine Sensitisation Test. Biologicals 2012, 40, 309-311. [CrossRef]

112. Wagner, L.; Isbrucker, R.; Locht, C.; Arciniega, J.; Costanzo, A.; McFarland, R.; Oh, H.; Hoonaker, M.; Descampe, B.; Andersen, S.; et al. In search of acceptable alternatives to the murine histamine sensitisation test (HIST): What is possible and practical? Pharmeur. Bio Sci. Notes 2016, 2016, 82-101.

113. Guerrant, R.L.; Brunton, L.L. Characterization of the Chinese hamster ovary cell assay for the enterotoxins of Vibrio cholerae and Escherichia coli and for specific antisera, and toxoid. J. Infect. Dis. 1977, 135, 720-728. [CrossRef] [PubMed]

114. Guerrant, R.L.; Brunton, L.L.; Schnaitman, T.C.; Rebhun, L.I.; Gilman, A.G. Cyclic adenosine monophosphate and alteration of Chinese hamster ovary cell morphology: A rapid, sensitive in vitro assay for the enterotoxins of Vibrio cholerae and Escherichia coli. Infect. Immun. 1974, 10, 320-327. [PubMed] 
115. Hewlett, E.L.; Sauer, K.T.; Myers, G.A.; Cowell, J.L.; Guerrant, R.L. Induction of a novel morphological response in Chinese hamster ovary cells by pertussis toxin. Infect. Immun. 1983, 40, 1198-1203. [PubMed]

116. Burns, D.L.; Kenimer, J.G.; Manclark, C.R. Role of the A subunit of pertussis toxin in alteration of Chinese hamster ovary cell morphology. Infect. Immun. 1987, 55, 24-28. [PubMed]

117. Gillenius, P.; Jaatmaa, E.; Askelof, P.; Granstrom, M.; Tiru, M. The standardization of an assay for pertussis toxin and antitoxin in microplate culture of Chinese hamster ovary cells. J. Biol. Stand. 1985, 13, 61-66. [CrossRef]

118. Xing, D.; Asokanathan, C.; Xu, X.; Bolgiano, B.; Douglas-Bardsley, A.; Zhang, S.; Wang, J.; Corbel, M. Relationship of immunogenicity to protective potency in acellular pertussis vaccines. Hum. Vaccin. Immunother. 2014, 10, 2066-2073. [CrossRef] [PubMed]

119. Fujiwara, H.; Iwasa, S. The quantitative assay of the clustering activity of the lymphocytosis-promoting factor (pertussis toxin) of Bordetella pertussis on Chinese hamster ovary (CHO) cells. J. Biol. Stand. 1989, 17, 53-64. [CrossRef]

120. Isbrucker, R.; Daas, A.; Wagner, L.; Costanzo, A. Transferability study of CHO cell clustering assays for monitoring of pertussis toxin activity in acellular pertussis vaccines. Pharmeur. Bio Sci. Notes 2016, 2015, 97-114.

121. Xing, D.; Das, R.G.; Newland, P.; Corbel, M. Comparison of the bioactivity of reference preparations for assaying Bordetella pertussis toxin activity in vaccines by the histamine sensitisation and Chinese hamster ovary-cell tests: Assessment of validity of expression of activity in terms of protein concentration. Vaccine 2002, 20, 3535-3542. [CrossRef]

122. Gupta, R.K.; Siber, G.R. Need for a reference preparation of pertussis antitoxin for Chinese hamster ovary cell assay. Biologicals 1995, 23, 71-73. [CrossRef]

123. Markey, K.; Douglas-Bardsley, A.; Hockley, J.; Costanzo, A. Calibration of pertussis toxin BRP batch 1 in a standardised CHO cell-based clustering assay. Pharmeur. Bio Sci. Notes 2018, 2018, 112-123. [PubMed]

124. Kataoka, M.; Toyoizumi, H.; Yamamoto, A.; Ochiai, M.; Horiuchi, Y. Chinese hamster ovary (CHO) cell clustering does not correlate with in vivo histamine-sensitization when measuring residual activity of aldehyde-treated pertussis toxin (PT). Biologicals 2002, 30, 297-302. [CrossRef] [PubMed]

125. Maaloe, O.; Jerne, N.K. The standardization of immunological substances. Annu. Rev. Microbiol. 1952, 6, 349-366. [CrossRef] [PubMed]

126. Cyr, T.; Menzies, A.J.; Calver, J.; Whitehouse, L.W. A quantitative analysis for the ADP-ribosylation activity of pertussis toxin: An enzymatic-HPLC coupled assay applicable to formulated whole cell and acellular pertussis vaccine products. Biologicals 2001, 29, 81-95. [CrossRef] [PubMed]

127. Yuen, C.T.; Canthaboo, C.; Menzies, J.A.; Cyr, T.; Whitehouse, L.W.; Jones, C.; Corbel, M.J.; Xing, D. Detection of residual pertussis toxin in vaccines using a modified ribosylation assay. Vaccine 2002, 21, 44-52. [CrossRef]

128. European Directorate for the Quality of Medicine. Collaborative Study for the Establishment of a European Pharmacpoeia Biological Reference Preparation for Pertussis Toxin-Part 1. Pharm. Spec. Issue Biol. 2001, 2001, 15-23.

129. Gomez, S.R.; Yuen, C.T.; Asokanathan, C.; Douglas-Bardsley, A.; Corbel, M.J.; Coote, J.G.; Parton, R.; Xing, D.K. ADP-ribosylation activity in pertussis vaccines and its relationship to the in vivo histamine-sensitisation test. Vaccine 2007, 25, 3311-3318. [CrossRef]

130. Gomez, S.R.; Xing, D.K.; Corbel, M.J.; Coote, J.; Parton, R.; Yuen, C.T. Development of a carbohydrate binding assay for the B-oligomer of pertussis toxin and toxoid. Anal. Biochem. 2006, 356, 244-253. [CrossRef]

131. Asokanathan, C.; Yuen, C.T.; Lin, N.; Xing, D. Investigation of effects of different commercial source of bovine serum albumin on the binding of pertussis toxin to the glycoprotein fetuin. Vaccine 2011, 29, 7593-7594. [CrossRef]

132. Yuen, C.T.; Horiuchi, Y.; Asokanathan, C.; Cook, S.; Douglas-Bardsley, A.; Ochiai, M.; Corbel, M.; Xing, D. An in vitro assay system as a potential replacement for the histamine sensitisation test for acellular pertussis based combination vaccines. Vaccine 2010, 28, 3714-3721. [CrossRef] [PubMed]

133. Xing, D.; Yuen, C.T.; Asokanathan, C.; Rigsby, P.; Horiuchi, Y. Evaluation of an in vitro assay system as a potential alternative to current histamine sensitization test for acellular pertussis vaccines. Biologicals 2012, 40, 456-465. [CrossRef] [PubMed]

134. Yuen, C.T.; Asokanathan, C.; Cook, S.; Lin, N.; Xing, D. Effect of different detoxification procedures on the residual pertussis toxin activities in vaccines. Vaccine 2016, 34, 2129-2134. [CrossRef] [PubMed] 
135. Isbrucker, R.; Arciniega, J.; McFarland, R.; Chapsal, J.M.; Xing, D.; Bache, C.; Nelson, S.; Costanzo, A.; Hoonakker, M.; Castiaux, A.; et al. Report on the international workshop on alternatives to the murine histamine sensitization test (HIST) for acellular pertussis vaccines: State of the science and the path forward. Biologicals 2014, 42, 114-122. [CrossRef] [PubMed]

136. Yuen, C.T.; Asokanathan, C.; Douglas-Bardsley, A.; Markey, K.; Rigsby, P.; Xing, D. Development of an in vitro Biochemical Assay System for the Measurement of Residual Toxin Activities in Pertussis Toxin Containing Vaccines. J. Vaccines Vaccin. 2017, 8. [CrossRef]

137. Ochiai, M.; Horiuchi, Y.; Yuen, C.T.; Asokanathan, C.; Yamamoto, A.; Okada, K.; Kataoka, M.; Markey, K.; Corbel, M.; Xing, D. Investigation in a murine model of possible mechanisms of enhanced local reactions to post-primary diphtheria-tetanus toxoid boosters in recipients of acellular pertussis-diphtheria-tetanus vaccine. Hum. Vaccin. Immunother. 2014, 10, 2074-2080. [CrossRef] [PubMed]

138. Carbonetti, N.H. Pertussis leukocytosis: Mechanisms, clinical relevance and treatment. Pathog. Dis. 2016, 74, ftw087. [CrossRef]

139. Adler, A.; Morse, S.I. Interaction of lymphoid and nonlymphoid cells with the lymphocytosis-promoting factor of Bordetella pertussis. Infect. Immun. 1973, 7, 461-467.

140. Morse, S.I.; Morse, J.H. Isolation and properties of the leukocytosis-and lymphocytosis-promoting factor of Bordetella pertussis. J. Exp. Med. 1976, 143, 1483-1502. [CrossRef]

141. Carbonetti, N.H. Contribution of pertussis toxin to the pathogenesis of pertussis disease. Pathog. Dis. 2015, 73, ftv073. [CrossRef]

142. Van Straaten-Van de Kappelle, I.; Van der Gun, J.W.; Marsman, F.R.; Hendriksen, C.F.; Van de Donk, H.J. Collaborative study on test systems to assess toxicity of whole cell pertussis vaccine. Biologicals 1997, 25, 41-57. [CrossRef] [PubMed]

143. Momose, H.; Mizukami, T.; Ochiai, M.; Hamaguchi, I.; Yamaguchi, K. A new method for the evaluation of vaccine safety based on comprehensive gene expression analysis. J. Biomed. Biotechnol. 2010, 2010, 361841. [CrossRef] [PubMed]

144. World Health Organization. Chapter IV: Testing for whole cell pertussis vaccine. In Manual for Quality Control of Diphtheria, Tetanus and Pertussis Vaccines; World Health Organization: Geneva, Switzerland, 2013; pp. 173-228.

145. Van Straaten-Van de Kappelle, I.; Wiertz, E.J.; Marsman, F.R.; Borsboom, D.J.; Van de Donk, H.J.; Kreeftenberg, J.G. The modified leukocytosis promoting factor (LPF)-test: A valuable supplement to the mouse weight gain (MWG)-test in toxicity control of whole cell pertussis vaccine. Biologicals 1992, 20, 277-282. [CrossRef]

146. Hoonakker, M.E.; Ruiterkamp, N.; Hendriksen, C.F. The cAMP assay: A functional in vitro alternative to the in vivo Histamine Sensitization test. Vaccine 2010, 28, 1347-1352. [CrossRef] [PubMed]

147. Hoonakker, M.E.; Verhagen, L.M.; Van der Maas, L.; Sloots, A.; Hendriksen, C.F. Reporter cell lines for detection of pertussis toxin in acellular pertussis vaccines as a functional animal-free alternative to the in vivo histamine sensitization test. Vaccine 2017, 35, 1152-1160. [CrossRef] [PubMed]

148. Vaessen, S.F.; Bruysters, M.W.; Vandebriel, R.J.; Verkoeijen, S.; Bos, R.; Krul, C.A.; Akkermans, A.M. Toward a mechanism-based in vitro safety test for pertussis toxin. Hum. Vaccin. Immunother. 2014, 10, 1391-1395. [CrossRef] [PubMed]

149. Hamaguchi, I.; Imai, J.; Momose, H.; Kawamura, M.; Mizukami, T.; Naito, S.; Maeyama, J.; Masumi, A.; Kuramitsu, M.; Takizawa, K.; et al. Application of quantitative gene expression analysis for pertussis vaccine safety control. Vaccine 2008, 26, 4686-4696. [CrossRef] [PubMed]

150. Vaessen, S.F.; Verkoeijen, S.; Vandebriel, R.J.; Bruysters, M.W.; Pennings, J.L.; Bos, R.; Krul, C.A.; Akkermans, A.M. Identification of biomarkers to detect residual pertussis toxin using microarray analysis of dendritic cells. Vaccine 2013, 31, 5223-5231. [CrossRef] [PubMed]

(C) 2019 by the authors. Licensee MDPI, Basel, Switzerland. This article is an open access article distributed under the terms and conditions of the Creative Commons Attribution (CC BY) license (http://creativecommons.org/licenses/by/4.0/). 